https://helda.helsinki.fi

\title{
Reciprocity and Wellbeing
}

\section{Karisto, Antti}

Routledge - Taylor \& Francis Group

2018

Karisto , A 2018 , Reciprocity and Wellbeing . in M Törrönen , C Munn-Giddings \& L

Tarkiainen (eds), Reciprocal Relationships and Well-being : Implications for Social Work and Social Policy . , 1, Routledge Advances in Social Work, Routledge - Taylor \& Francis Group , London , pp. 11-25 . https://doi.org/10.4324/9781315628363-2

http://hdl.handle.net/10138/313312

https://doi.org/10.4324/9781315628363-2

cc_by_nc_nd

publishedVersion

Downloaded from Helda, University of Helsinki institutional repository.

This is an electronic reprint of the original article.

This reprint may differ from the original in pagination and typographic detail.

Please cite the original version. 


\title{
1 Reciprocity and well-being
}

\author{
Antti Karisto
}

\section{Introduction}

[E]ach gift is part of a system of reciprocity in which the honours of giver and recipient are engaged. It is a total system in that every item of status or of spiritual or material possession is implicated for everyone in the whole community. The system is quite simple: just the rule that every gift has to be returned in some specified way sets up a perceptual cycle of exchanges within and between generations. In some cases the specified return is of equal value, producing a stable system of statuses; in others it must exceed the value of the earlier gift, producing an escalating contest of honour. The whole society can be described by the catalogue of transfers that map all the obligations between its members. The cycling gift system is the society.

(Douglas 1990, viii-ix)

The quote above by Mary Douglas reflects the ethos of the present chapter, in which I explore the essence of reciprocity from the viewpoint of wellbeing. Let me, however, begin by recollecting a personal memory that led me to consider the theme. A quarter of a century ago, I visited the School for Advanced Urban Studies, which operates under the auspices of the University of Bristol. At the end of the week, the researchers had the habit of going down to the pub. The evening proceeded in such a way that one would offer a round to everyone, and then it would be the turn of the next. There were around ten of us, and I became restless when I thought about when it would be my turn. Why on earth should I offer drinks to such a large group of people, most of whom I hardly knew? Perhaps I would buy a round next Friday or the Friday after. Or should I offer to buy it now to avoid being labelled a freeloader and risk losing face?

I decided to raise the topic of buying rounds, and the rules of the game were explained to me. Naturally, no record was kept of who had bought what; you simply trusted that everyone would commit, more or less, to the principle of reciprocity. If one Friday night did turn out to be expensive, 
you got to drink for free on many following Fridays, and in the long run, everything would work out fair and square. As a temporary guest, I wasn't expected to buy a round, but these urban sociologists in the pub were extremely surprised at my description of Finnish pub culture, where everyone buys their own drinks, or, if not, they settle up during the same night.

My pub experience gave me food for thought; it forced me to ponder offering and reciprocity. Offering can be an empty word; reciprocity can be spurious. If accounts are immediately settled, then the bother of paying is just passed from one person to another, in turn. With mechanical reciprocity, the boozing continues, but the kind of reciprocity that really sweetens life seems to require something else: disinterested willingness to give, spontaneous broad-mindedness, tactful understanding of the situation and appreciation of the nature of the good life.

In this chapter, I investigate reciprocity and its importance in the creation of well-being. I begin by making a few observations about cultural variation in everyday social intercourse and then move on to the level of concepts. If reciprocity is a difficult notion open to many interpretations, then so is well-being. A confusing factor is that there are several competing discourses on well-being, and the significance of reciprocity varies between them. I will give particular thought to well-being in human relationships as reciprocity is connected to them almost by definition. I will also examine the kind of 'general reciprocity' that occurs in social policy and social work. Finally, I investigate reciprocity in old age and in intergenerational relations. When we are old, we are particularly dependent on one another, and the sustainability of our well-being requires a 'generationally intelligent' social policy.

\section{Culturally defined forms of reciprocity}

As a Finn, I am accustomed to the exchange of words in everyday comings and goings being rather terse. In his novel, Hannu Raittila presents this in an indisputable way:

In speech in foreign languages a Finn is always disturbed by the fact that sentences have all kinds of unnecessary phrases and politeness forms. They make the language difficult and awkward to speak and obscure its meaning. In Finnish, the matter is said in the simplest and most unambiguous way possible, and then we wait to see what the other replies. If there is nothing to say, we are silent.

(Raittila 2001, p. 40)

We are often silent. Linguists have characterised reticence and 'minimal politeness' as being typical of Finns. We react to open rudeness, but we do not expect language to be particularly polite (e.g. Jaakkola 2008, pp. 113-115). Does Finland suffer from a particular deficit of politeness and respect of the kind that Richard Sennett (2003) considers to be a unifying feature of modern societies? Finns are certainly capable of saying 'thank you', but one 
symptom of the paucity of explicitly polite reciprocity that is embedded in the Finnish language or mind is our lack of an equivalent for the useful word 'please'. Well, of course, we have the phrasal equivalents ole hyvä and olkaa hyvä (literally 'be good'), but using them is already something of an effort: You need to use two words and choose between the formal and informal form of address. Perhaps for this reason, these words are used far less than quickly delivered words in many other languages (Karisto 2010, pp. 74-77). In Finnish, kiitos ('thank you') is like a full stop. You can reply to it with eipä kestä ('no problem') or the more ceremonious kiitos on minun puolellani ('my pleasure'; literally, 'the gratitude is on my side'), but those phrases have the same tone: That's enough thanking! Obligatory phrases are recited, but reciprocity is not expected to continue over and above this point.

Finland is considered a low context culture in which people typically attempt to produce so-called first-level descriptions. Things are said 'the way they are'; the relationship between speech and its subject is considered unambiguous. This contrasts with second-level descriptions or high context cultures in which speech does not refer so much to reality as to other speech concerning that reality (Daun 1989, Baudrillard 1991, see Alapuro 1997, pp. 184-186).

The division between low or high contexts or first and second levels is, of course, a generalising typology that may exaggerate cultural differences. There is no reason to consider a paucity of reciprocity to be an essential characteristic of Finnish culture or brand Finnish manners as shoddier or coarser than those of other cultures. While in other cultures, politeness is cultivated more intensely, social interaction is not necessarily more warmhearted. It is unlikely that Brits are always as thoroughly broad-minded and generous as they implied in that Bristol pub. And perhaps it is an example of 'orientalism' (Said 2011) to think that reciprocity is always the spice of life in Eastern cultures. For example, benevolence and sympathy (amae) are said to be at the centre of the Japanese way of life. Gifts are given in many situations, for instance, when a colleague's daughter gets married, irrespective of whether one personally knows the individual concerned or not. A gift is always followed by a reciprocal gift, but the exchange of gifts is normatively regulated and carefully apportioned. A reciprocal gift cannot be too modest or too extravagant; in some situations, it must be a defined fraction of the value of the gift received. This even obliges people to keep a written record of the gifts they have received and discover their monetary value (Davies and Ikeno 2002, pp. 238-239). But doesn't norm-driven, carefully calculated reciprocity feel more like an obligation than real reciprocity (see also Becker 1986, pp. 73-74)?

Forms of reciprocity are culturally specific, and it is difficult to place them in rank order. Forms of reciprocity are also malleable. In recent years, there has been a greater abundance of Finnish phrases and expressions; linguistic reciprocity has clearly become richer. The new generation of service sector workers draws its influences from practices abroad, and presumably people in Finnish pubs also behave differently from my generation in its youth. 


\section{Organic reciprocity, not a mechanistic exchange}

The kind of reciprocity that boosts well-being does not need to be of the expressive, effusive kind; rather, it can also be realised in a restrained Finnish way, without melodrama. Nonetheless, in some way, it must be flexible and organic. Reciprocity includes giving, even if we do not immediately receive something in return. Reciprocity can only be realised over the course of time, and it does not always need to occur. It can be more of a disposition: a general willingness to do good for others. For example, the core of friendship is just this willingness. We have friends, so we can turn to them, even if we don't actually turn to them, and although they cannot always help. The modern understanding of friendship, in contrast, is freedom from binding obligations (Pahl 2000, p. 37). Hospitality is another model for reciprocity and searching for a good life. For example, the sharing of meals is meant to be continual. The pattern 'give, receive, give in return...' identifies an open-ended process in which some imbalance is always present (Boisvert and Heldke 2016, p. 51).

In reciprocity that occurs in social interaction, there must be space for situational sensitivity (Naukkarinen 2011). Spontaneity and surprise are good - there is little enjoyment in getting something one was already certain of receiving. It feels much better to receive something unexpectedly and from an unlikely source.

Nonetheless, an entirely predictable, mechanistic exchange, or what Serge-Christophe Kolm (2000a, p. 14) terms 'self-sustained sequential exchange', also has its uses. It is better that norms oblige us to perform friendly gestures rather than entice us to engage in misanthropy. Even mechanical or superficial reciprocity maintains a sense of community, and neglecting it can be fatal in the same way that open arrogance is. However, mechanical reciprocity is hardly a bottomless wellspring of well-being, and neither is simply refraining from impoliteness. Well-being is something more than a lack of problems and grievances or their successful regulation - contrary to common thinking in social policy and social work, where well-being and welfare are often conflated. In Finnish, there is also confusion due to the fact that the word hyvinvointi is used to describe the good life of an individual (well-being), the good produced by the welfare state (welfare) and any form of indulgent and momentary gratification (wellness). Even actual well-being has many forms, and the Finnish sociologist Erik Allardt (1976), for example, divides it into three broad dimensions: Having, Loving and Being.

\section{The many forms of well-being}

Not all forms of reciprocity are good as reciprocity can also involve revenge for ill treatment. However, my focus here is on reciprocity that is beneficial in one way or other - but beneficial for what? Well-being, like reciprocity, is a multifaceted and slippery concept. Although the nature of the good life 
has been pondered for millennia and the multiplicity of well-being has often been emphasised, in public discourse, it is basically understood as Having, i.e. the material goods that a person possesses. In publicity, well-being is embedded in the economy. It is believed that well-being is produced when the economy is left to function free from interference. The well-being of the economy is an issue of absolute primacy because it is considered to trickle down to create individual well-being.

Even if the economic approach to well-being has become dominant, it is by no means the only perspective. There are several competing discourses on well-being, and the significance of reciprocity varies between them. For promoters of health, well-being, above all, means a healthy and wellfunctioning body. In social policy, it is the good produced by the welfare state, the regulation of poverty and other problems - at bottom, security. From an ecological perspective, sustainability is the crucial precondition of well-being. It may mean transcendental or aesthetic peak experiences and so on. Well-being is much discussed, but one person understands it one way and the next in a different way. Politicians and other actors are quick to appeal to well-being because it is the magic word that also seems to legitimise the pursuit of their particular interests (Karisto 2010, pp. 15-19).

Reciprocity has been highly prominent in economic notions of wellbeing (e.g. Gérard-Varet et al. 2000, Gintis 2000a, 2000b). In fact, it has been economists who have developed the formal theory of reciprocity game theory - the furthest. In particular, the theme of reciprocity has been cultivated in discussions on alternatives to a pure market economy: caring economy, social enterprises and corporate social responsibility, women's banks and microcredit and finance, fair trade practices and time banking, in which the transfer of services does not involve the exchange of money but the exchange of time and services provided for others (Bruni 2008, Koskiaho 2014, Hirvilammi 2015).

Nevertheless, reciprocity has been even more widely discussed in the social sciences, psychology, anthropology and moral philosophy. In these disciplines, reciprocity and economic exchange are considered two different, even mutually exclusive, principles of exchange (Polanyi 2001, p. 47, Kujala and Danielsbacka 2015, pp. 20-21 and 39-43). For example, the Swedish sociologist Sten Johansson has warned about mixing the rules of private and economic life, terming it 'prostitution', the confusing of political and economic spheres 'corruption' and the intermingling of political and private life 'nepotism' (Johansson 1979, pp. 101-103). According to Niklas Luhmann, social subsystems - the economy, politics, the welfare state, science, art, the media and others - are 'autopoietic', i.e. self-referential. There is interaction between them, but each has its own way of communicating, its own 'medium' and its own 'code' (Jalava and Kangas 2013). Things turn out badly if the medium of one subsystem becomes dominant in the other subsystems, with corruption and prostitution being among the consequences when 'money talks'. 
Loving, of course, is closer to reciprocity than the other dimensions of well-being distinguished by Allardt (1976). Some level of reciprocity is an absolute precondition for well-being based on human relations. The kind of partnership or friendship where flows of support and emotion only travel in one direction is doomed to fail. The social exchange that occurs among family and friends is sometimes considered the only genuine form of reciprocity (see Kolm 2000a, p. 28, Bruni 2008, p. xii). Perceived well-being is strongly affected by the reciprocity that occurs in social interaction: whether we receive love and whether we give it, and how we value and treat one another. In people's own interpretations of their well-being, human relationships, alongside health, are considered the most significant factors (e.g. Haapola et al. 2013, p. 84).

Well-being accumulates in different ways in its different dimensions. While hankering after Having, it might feel that well-being grows at the expense of others as there is only a certain amount of material goods to be divided at any one time. Well-being built on human relationships, in contrast, does not diminish, even if it is given to others. On the contrary, those who enjoy the greatest well-being are those for whom goodwill and care for the well-being of their nearest and dearest are important (Sortheix 2014).

The various dimensions of well-being relate differently not only to reciprocity but to one another. For example, poor health is a corrosive disadvantage (Wolff and De-Shalit 2007) as when health is lost, other forms of well-being threaten to vanish. Nonetheless, even if a person is in perfect health, this will not necessarily increase her other forms of well-being. In contrast, good human relationships and reciprocity are thought to have a fertile functioning, i.e. a particular ability to promote other forms of wellbeing (ibid.) and to prevent them from being negatively impacted by various kinds of loss. According to Alvin W. Gouldner (1960), reciprocity may also initiate social cooperation in the early phases of group consolidation, in which others are easily viewed with suspicion, e.g. in interaction between immigrants and nationals (Manatschal 2015, p. 243).

\section{Demanding reciprocity}

Alongside warm interpersonal emotions, cool intellect is also reciprocal. According to the Swedish essayist Horace Engdahl (2013, p. 33), the criteria for intelligence lie 'not in the ability to say profound things but in the ability to listen. Intelligence requires two brains, their interplay'.

It is through reciprocity that we find our place in the world (Thompson 2013, p. 39). Our identities are constructed on the basis of our social interactions with others and our abilities to see the world through others' eyes. 'Through the thou a person becomes I', wrote Martin Buber (1999, p. 52). Similarly, Emmanuel Levinas reminds us that being true to ourselves includes having a sense of responsibility towards others (see Sennett 1999, p. 145). 
Reciprocity is good for both the individual and the community. It reinforces human relationships, increases trust and expands cultural and social capital. Nevertheless, it is not an automatic dispenser of happiness. Martha Nussbaum (2001, see Bruni 2008, pp. 8-9) has emphasised the enormous significance of friendship, love and other relational goods but has also spoken of their fragility. Reciprocity in human relations is never certain. On the contrary, well-being connected to human relationships is unstable, and virtuous circles built on reciprocity are easily broken. According to Fransesco Alberoni (1989), nothing beyond the new relationship seems to have space in the consciousness of someone who has fallen in love, and this source of well-being feels completely inexhaustible. Nevertheless, the rapture produced by being in love is generally just momentary ecstasy, and the hubris of well-being can be followed by its nemesis. If all goes well, the lovers' tumultuous emotions coalesce into life-affirming prosaic love, but for the less fortunate, love evaporates and even becomes its opposite: hate.

The problem with well-being based on Having is that we are never satisfied. A successful purchase only brings a momentary glow; there never seems to be enough material well-being. However, a similar kind of 'pursuit of the unattainable' (Ehrnrooth 1995) also features in reciprocity. Such high demands are placed upon it that we can never entirely realise them.

In the ethics of reciprocity, a famous ideal type is agápe: pure altruistic love - i.e. the kind that is "patient and kind, does not envy or boast, is not arrogant or rude, does not insist on its own way, is not irritable or resentful, and does not rejoice at wrongdoing'. However, this kind of love, which 'bears all things, believes all things, hopes all things, and endures all things', seems to be above and beyond the kind of reciprocity found in everyday life (Bruni 2008, p. 50). 'Do unto others as you would have them do unto you' is the golden rule of ethics, but in practice, we never realise this in its entirety. Nonetheless, the mighty precept is necessary. Although (or precisely because) we are forced to live our everyday lives in the framework of factual necessities, moral guidelines and 'the principle of hope' have their purposes (e.g. Ehrnrooth 2014). 'Pursuit of the unattainable', the attempt to reach beyond actual reality, is said to be a characteristic striving of people living in the Western world (Ehrnrooth 1995, pp. 34-50), but the golden rule of ethics and its variations are certainly recognised in other cultures (e.g. Thompson 2013, p. 35). This is also proof of the universal value of reciprocity.

In moral philosophy, there are numerous variants of the golden rule. Immanuel Kant's categorical imperative obliges us to place ourselves in another person's shoes and act in such a way that our actions could become a universal law. The face was the central metaphor used by Levinas (1996) when writing about encountering another person. When we look another person - even a stranger - in the face, we should be ready to take responsibility for that person. Buber's (1999) comparable ethical imperative was Thou, which is entirely different to the It of objectified human relationships. According to Buber, we should live in the world of Thou and cherish the 
I-Thou relationship so that the goal of altruistic reciprocity is realised: 'between the I and the Thou there is no striving, no demands nor anticipation' (ibid., p. 34).

Ethical ideals linked to reciprocity are a kind of compass for well-being: They give us the direction in which to strive and perhaps also the power to do so. Raymond D. Boisvert and Lisa Heldke (2016, pp. 59-65) appoint Jane Addams, a pioneer of social work, as an 'inspirational individual' who kept alive the sense of reciprocal dependence. Three ethical principles were adopted in Hull House, a neighbourhood settlement for immigrants that was founded by Addams: 'to teach by example, to practice cooperation, and to practice social democracy, that is, egalitarian, or democratic, social relations across class lines' (Knight 2005, p. 182). In practice, Hull House offered a comprehensive set of social services and cultural, recreational and educational activities for people who could hardly be more different from the people with whom Addams herself grew up (Boisvert and Heldke 2016, p. 63).

\section{The limitations of reciprocity}

Sociology and anthropology have focussed more on describing the practical forms of reciprocity and solidarity that appear in communal life than on their ethical requirements or content in an ideal world. It is comforting to note that in practice, people do not always think only of their immediate benefits. Empathy, generosity and offering, in other words reciprocity, are found in every society - even in modern society, where it is feared that the individual, in pursuit of personal gain, will trample others under foot in an atmosphere of heightened individualism.

Nonetheless, according to Marcel Mauss (1999), a gift is not given without an expectation that the giver will receive a gift in return. We compete even in munificence; even a debt of gratitude is a debt. In the closest human relationships, interaction can still be directed by altruistic benevolence in which help is given, even at the expense of the well-being of the helper. Outside such relationships, a precondition for giving is nevertheless that it is worthwhile or cost-effective. Expressed in plain technical terms, helping is worthwhile if the cost is 'smaller than the benefit of the expected return service times the probability of receiving that service' (Danielsbacka 2013, p. 31).

According to evolutionary psychologists, the desire to help is genetically encoded within us, but it is more likely to be directed towards those who are close to us. How far the circle of empathy extends in practice is dependent on the cultural environment (Pinker 2011, p. 668, Danielsbacka 2013, p. 30). It usually includes family members, who receive help almost unconditionally. In contrast, helping friends is already bound up with the quality of each individual relationship and the general norms that govern friendships. Altruistic giving is, after all, the exception, but so is the exclusive pursuit of personal gain; most commonly, we operate between these two extremes (Kolm 2000b, p. 115). 
Nowhere does the circle of empathy extend limitlessly. It covers 'us' but not 'them' or 'others'. It is no wonder that Sennett (1999, pp. 136-139) considers the pronoun 'we' to be so dangerous. By cultivating it, we strengthen our circles of empathy and build their internal senses of community, but the word 'us' is also swiftly repeated when excluding 'others'. If empathy and reciprocity are genetically programmed, then so is the binary opposition of 'us' and 'them', and this opposition can be reproduced in the name of 'us'.

When discussing 'the corrosion of character', Sennett (1999) claims that reciprocity is weakened by societal changes. Under the conditions of new neoliberal capitalism, people are forced to adopt an individualistic 'flexibility', and reciprocal loyalty is no longer the self-evident foundation of communal life. According to Sennett, a character that is incapable of empathy will become more common. This has also been discussed by Christopher Lasch (1979) in his analysis of the culture of narcissism and was detailed decades before by Georg Simmel (1903/2005, pp. 33-36) in his description of the reserved habitus of people raised in modern urban society. In the metropolis, it is simply impossible to encounter others as whole personalities. One cannot look them in the face, cannot become involved in all their possible woes and troubles - not without finding oneself in a 'completely unbearable spiritual state', at least (ibid., p. 35). We learn to pass others by.

The dominant form of solidarity in modern society is said to be negative solidarity, which is demonstrated by not interfering in the business of others (Kortteinen 1982, pp. 251-252). That, too, is solidarity, and a certain form of reciprocity, as we do not expect others to interfere in our affairs either. Although non-interference and the reciprocal guarding of each other's privacy are a necessity of sorts and sometimes even an indication of tact, nonetheless, they should not be turned into a virtue. On the contrary, negative solidarity easily leads us to view 'others' as simply not being there at all: We do not harm them, but nor do we respect them; they are simply ignored. Those on the fringes, or outside, of the circle of empathy go unnoticed and are easily abandoned. Simmel was conscious of this when writing about how aloofness or indifference towards others - which he also considered to be a guarantee of personal freedom - can, in an instant, 'break into hatred and fight' (Simmel 2005, p. 35). Buber crystallises the relationship between positive and negative solidarity by stating that a person must live in the world of It but 'he who lives with It alone is not a man' (Buber 1999, p. 34).

\section{Welfare state reciprocity}

In recent times, increasing calls have been made for people to take greater care of one another rather than leaving this care to the welfare state. It is nevertheless unrealistic to imagine that in families and local communities, entirely untapped reciprocal resources lie dormant, as is claimed by those supporting individual solutions or advocating for implicit familialism' (Leitner 2003). Because the circle of moral responsibility does not 
necessarily extend very far, not everything can rest on individual behaviour. If we cannot look 'others' in the face, their needs can be addressed through social policy and social work. Reciprocity that produces well-being is not only interaction between individuals; rather, social life and social policy are 'fundamentally a question of reciprocity' (Kolm 2000a, p. 16, Bruni 2008, pp. ix-xii).

Richard Titmuss's (1970) famous example of general or indirect reciprocity was that of giving blood. Blood donors do not expect payment or any other immediate gift in return. They do not even know who will receive the blood they have donated - just as they do not know the purpose for which their individual tax payments will be used. Blood donors and taxpayers simply trust that reciprocity will occur: Tax revenue will also be used for their benefit, and they will be given blood if they happen to need it.

Jyri Liukko, a Finnish researcher of social policy, has dubbed social insurance to be a 'solidarity machine'. Social insurance is a moral technology that makes solidarity automatic, and which 'is always in some way linked to collaborative action and reciprocity' (Liukko 2013, p. 8). Similarly, the entire welfare state can be considered an institution that is based on and realises general reciprocity.

General reciprocity, however, is not symmetrical in the same way as genuine reciprocity between individuals might be. One does not receive services and income transfers that are directly equated to one's tax contributions. Means testing results in help being given to those who need it the most. Social support differs from true reciprocity in terms of its redistributive nature, but it can also be understood as 'delayed reciprocity' or as investment. In the long run, society enjoys a return on its investment, and the public good accumulates. Social investments nevertheless require time; the return may be long in coming, and sometimes, there is no payback for the help provided. For this reason, too, the public sector is better suited to making social investments and engaging in general reciprocity than are private actors (Sipilä 2011, p. 363).

\section{Reciprocity in old age and in intergenerational relationships}

In general, there is no need to understand reciprocity solely as one giving something to another, who, in turn, gives something of equal worth in return. For example, intergenerational reciprocity is often based on 'chains': A gives to B and B, in turn, gives to C (Kolm 2000a, p. 7, Kolm 2008, pp. 16, 46 and 79). The older generation pays for the younger generation's schooling, and the latter pays for the education of the next. An example of a chain in the other direction, and of general reciprocity, is pension policy. In pay-as-you-go pension systems, the lion's share of workers' pension contributions is used to pay the pensions of those already retired, and the workers must trust that this practice will continue in the future, when they too have retired. 
Taking care of one's own children is a universally internalised obligation. In many countries, the interests of children are also enshrined in law, and if parents seriously neglect these interests, then their parenthood can be limited. In contrast, in Finland, there are no statutory obligations to care for one's parents, but, of course, there are normative obligations. From the perspective of their well-being, it is important that the elderly receive the care they need and can also otherwise interact with members of the younger generation. Intergenerational social intercourse is important to the elderly (Bengtson 2001), but young people also desire it, at the latest when they become old themselves and want to maintain contact with their own children and grandchildren.

For elderly people, reciprocity is a particularly central source of wellbeing; without it, it is futile to speak of successful ageing. Elderly people typically expect that others will have the time for social intercourse, and this concerns both intimate relationships and professional care. Of course, a professional carer also gains a sense of pleasure from having the time to properly encounter others as whole human beings rather than as the latest home help customers of the day. However, for professional carers, time is often short. Care work is organised in the same way as other forms of production, and this prevents the deepening of reciprocity. A conflict arises between 'doing and encountering' (Palomäki and Toikko 2007).

In spite of its apparent asymmetry, care is also essentially reciprocal. Care is about concern for others and taking responsibility, looking after others and carrying their cares (Fisher and Tronto 1990). It is a relational activity, based on mutual dependency (Martela 2012), whose telos is restoring the autonomy of the care receiver (De Lange 2011). Care requires reciprocal tact, adapting oneself to the pace and rhythm of the other (see Naukkarinen 2011). For example, in family care, the reciprocal functions of the provider and the recipient of care complement each other so subtly that it is sometimes impossible to distinguish the role of the carer from that of the recipient (Andersson 2007). Nevertheless, there is often a divide between these roles; for example, someone suffering from severe dementia can be entirely at the mercy of others. The abilities to engage in reciprocity and accept responsibility are particularly tested when the other person no longer seems to be an autonomous agent nor appears capable of giving anything.

Bryan S. Turner (1989, Pilcher 1995, p. 105) sees the precarious social status of the elderly as resulting from their often being solely recipients of care and help when their abilities to give and to engage in immediate reciprocity have diminished. This can be fateful in a society where 'the ideology of social parasitism' prevails, and helplessness is a sign of weakness and dependence on others a mark of shame (Sennett 1999, p. 139-140). When we have started to measure the 'success' of old age against the ideal of productive ageing, in which the greatest value is given to work and work-like activities, we no longer understand that those who have become helpless and unfit for work also have, and particularly have had, something to give. 
Jari Pirhonen (2015), who has adapted Charles Taylor's (1992) and Axel Honneth's (2005) recognition theory to eldercare in Finland, is concerned that the humanity of incapacitated elderly people will be lost in their 'patienthood' or 'customership'. Indeed, this will happen if the elderly are seen merely as clients, patients or medical cases rather than as whole human beings and unique biographical creatures. A new kind of professionalism, informed by theories of reciprocity and well-being, is also needed in eldercare. This professionalism is 'generationally intelligent' (Biggs and Lowenstein 2011) when it is sensitive to the life-courses and lifeworlds of 'clients' who belong to different generations than their carers.

Our thinking about old age is far too polarised, placed either in a framework of choices or a framework of necessities. Incapacity and dependence on others seem completely incompatible with activeness and autonomy, which are nowadays so strongly emphasised (Kröger et al. 2007, pp. 11-13). In old age, agency and activeness are important, but they are often understood only narrowly, through rationalistic choices and in terms of productive activities (Grenier and Phillipson 2013). Referring to Alasdair MacIntyre (1999, pp. 1-9), Pirhonen (2015) writes that

humanity is not defined by rationality and self-determination, but by biology, frailty and dependence. We are born completely dependent, we create the illusion of self-determination during our adulthood and we are forced to recognise our dependence once more as our capacity declines with aging.

Simon Biggs and Ariela Lowenstein (2011) call for generational intelligence, a form of reflexive reciprocity, in both private and public life. They advocate that our perspectives should not be defined simply by the typical aims of our own age groups and generations and our own immediate benefits and desires. We should remember the existence of other generations and understand that they too have legitimate interests, which are balanced with our own in social policies.

It is particularly difficult for us to empathise with those generations yet to be born. Nevertheless, we must do this (Kolm 2000a, p. 29) as it is a requirement of the social sustainability of well-being. The state of the world should be at least as good when we leave it as when we were born into it (Becker 1986, p. 228). We must also offer something to future generations, and we cannot ask them to pick up our tab just because they won't have a chance to buy us a round.

\section{References}

Alapuro, R., 1997. Suomen älymystö Venäjän varjossa. Helsinki: Tammi.

Alberoni, F., 1989. Rakastuminen. Helsinki: Otava. (Original: Innamoramento e amore. Milano: Aldo Garzanti Editore, 1979.) 
Allardt, E., 1976. Hyvinvoinnin ulottuvuudet. Helsinki: WSOY.

Andersson, S., 2007. Kahdestaan kotona - tutkimus vanhoista pariskunnista. Helsinki: Stakes, tutkimuksia 169.

Baudrillard, J., 1991. Amerikka. Helsinki: Loki-kirjat. (Original: Amérique. Paris: Editions Grasset \& Fasquelle, 1986.)

Becker, L. C., 1986. Reciprocity. London and New York: Routledge \& Kegan Paul.

Bengtson, V. L., 2001. Beyond the Nuclear Family: The Increasing Importance of Multigenerational Bonds. Journal of Marriage and Family 63(1):1-16.

Biggs, S., and Lowenstein, A., 2011. Generational Intelligence. A Critical Approach to Age Relations. London: Routledge.

Boisvert, R. A., and Heldke, L., 2016. Philosophers at Table. On Food and Being Human. London: Reaktion Books.

Bruni, L., 2008. Reciprocity, Altruism and the Civil Society. In Praise of Heterogeneity. London: Routledge.

Buber, M., 1999. Minä ja Sinä. Helsinki: WSOY. (Original: Ich und Du. Leipzig: Insel-Verlag, 1923.)

Danielsbacka, M., 2013. Vankien vartijat. Ihmislajin psykologia, neuvostosotavangit ja Suomi 1941-1944. Historiallisia tutkimuksia Helsingin yliopistosta XXXII. Helsinki: Helsingin yliopiston filosofian, historian, kulttuurin ja taiteiden tutkimuksen laitos.

Daun, Å., 1989. Svensk mentalitet. Stockholm: Nordsteds Akademiska Förlag.

Davies, R. J., and Ikeno, O., 2002. The Japanese Mind. Understanding the Contemporary Japanese Culture. North Clarendon, VT: Tuttle.

De Lange, F., 2011. Restoring Autonomy. Symmetry and Asymmetry in Care Relations. Nederduitse Gereformeerde Teleogiese Tydskrif 52, 61-68.

Douglas, M., 1990. Foreword. No Free Gifts. In: Mauss, M. ed. The Gift. The Form and Reason for Exchange in Archaic Societies. London: Routledge, vii-xviii.

Ehrnrooth, J., 1995. Asentoja. Muistelmia nykyajasta. Helsinki: WSOY.

Ehrnrooth, J., 2014. Toivon tarkoitus. Helsinki: Kirjapaja.

Engdahl, H., 2013. Ja sen jälkeen savuke. Helsinki: Siltala. (Original: Meteorer. Stockholm: Albet Bonniers Förlag, 1999.)

Fisher, B., and Tronto, J., 1990. Toward a Feminist Theory of Caring. In: Abel, F. and Nelson, M. eds. Circles of Care. Albany: State University of New York, 35-62.

Gérard-Veret, L. A., Kolm, S. C., Ythier, J., and Mercier, J. eds. 2000. The Economics of Reciprocity, Giving and Altruism. Basingstoke: Macmillan Press.

Gintis, H., 2000a. Beyond Homo Economicus: Evidence from Experimental Economics. Ecological Economics 35:311-322.

Gintis, H., 2000b. Strong Reciprocity and Human Sociality. Amherst: University of Massachusetts, Economics Department Working Paper Series 82.

Gouldner, A. W., 1960. The Norm of Reciprocity: A Preliminary Statement. American Sociological Review 2, 161-178.

Grenier, A., and Phillipson, C., 2013. Rethinking Agency in Late Life: Structural and Interpretive Approaches. In: Baars, J., Dohmer, J., Grenier, A., and Phillipson, C., eds. Ageing, Meaning and Social Structure. Connecting Humanistic and Critical Gerontology. Bristol: Policy Press.

Haapola, I., Vaara, E., and Karisto, A., 2013. Koettu hyvinvointi. In: Haapola, I., Karisto, A. and Fogelholm, M., eds. Vanhuusikä muutoksessa. Ikihyvä PäijätHäme-tutkimuksen tuloksia 2002-2012. Päijät-Hämeen sosiaali- ja terveysyhtymän julkaisuja 72, 83-90. 
Hirvilammi, T., 2015. Kestävän hyvinvoinnin jäljillä. Ekologisten kysymysten integroiminen hyvinvointitutkimukseen. Helsinki: Kela, Sosiaali- ja terveysturvan tutkimuksia 136.

Honneth, A., 2005. The Struggle for Recognition. The Moral Grammar of Social Conflicts. Cambridge: Polity Press.

Jaakkola, L., 2008. “Mitäs sulle?” Kohtelias asiakaspalvelu ikääntyvien ja ikääntyneiden tulkinnoissa. Soveltavan kielentutkimuksen lisensiaattityö. Jyväskylän yliopisto.

Jalava, J., and Kangas, R., 2013. Kommunikaatio, yhteiskunnan eriytyminen ja osasysteemien merkitys. In: Jalava, J., ed. Yhteiskunnan järjestelmät. Niklas Luhmannin ajattelu. Helsinki: Gaudeamus, 40-59.

Johansson, S., 1979. Mot en teori för social rapportering. Stockholm: Institutet för social forskning, Rapport $\mathrm{Nr} 2$ från levnadsnivåprojekt.

Karisto, A., 2010. Yksi piano vai kymmenen lehmää? Kirjoituksia arjen ilmiöistä. Helsinki: Gaudeamus.

Knight, L. W., 2005. Citizen: Jane Addams and the Struggle for Democracy. Chicago: University of Chicago Press.

Kolm, S. C., 2000a. Introduction: The Economics of Reciprocity, Giving and Altruism. In: Gérard-Veret, L. A., Kolm, S. C., Ythier, J., and Mercier, J., eds. The Economics of Reciprocity, Giving and Altruism. Basingstoke: Macmillan Press, 1-46.

Kolm, S. C., 2000b. The Theory of Reciprocity. In: Gérard-Veret, L. A., Kolm, S. C., Ythier, J. and Mercier, J., eds. The Economics of Reciprocity, Giving and Altruism. Basingstoke: Macmillan Press, 115-141.

Kolm, S. C., 2008. Reciprocity. An Economics of Social Relations. Cambridge: Cambridge University Press.

Kortteinen, M., 1982. Lähiö. Tutkimus elämäntapojen muutoksesta. Helsinki: Otava.

Koskiaho, B., 2014. Kumppanuuden sosiaalipolitiikkaa etsimässä. Helsinki: Suomen Setlementtiliitto.

Kröger, T., Karisto, A., and Seppänen, M., 2007. Sosiaalityö vanhuuden edessä. In: Seppänen, M., Karisto, A., and Kröger, T., eds. Vanhuus ja sosiaalityö. Sosiaalityö avuttomuuden ja toimijuuden välissä. Jyväskylä: PS-Kustannus, 7-15.

Kujala, A., and Danielsbacka, M., 2015. Hyvinvointivaltion loppu? Vallanpitäjät, kansa ja vastavuoroisuus. Helsinki: Tammi.

Lasch, C., 1979. The Culture of Narcissism. American Life in an Age of Diminishing Expectations. New York: W.W. Norton.

Leitner, S., 2003. Varieties of Familialism. European Societies 5, 353-375.

Levinas, E., 1996. Etiikka ja äärettömyys. Keskusteluja Philippe Nemon kanssa. Helsinki: Gaudeamus. (Original: Ethique et infini. Dialogues d'Emmmanuel Levinas et Philippe Nemo, 1981.)

Liukko, J., 2013. Solidaarisuuskone. Elämän vakuuttaminen ja vastuuajattelun muutos. Helsinki: Gaudeamus.

MacIntyre, A., 1999. Dependent Rational Animals. Why Human Beings Need the Virtues. Chicago and La Salle, IL: Open Court.

Manatschal, A., 2015. Reciprocity as a Trigger of Social Cooperation in Contemporary Immigration Societies? Acta Sociologica 3, 233-248.

Martela, F., 2012. Caring Connections - Compassionate Mutuality in the Organizational Life of a Nursing Home. Aalto University Publication Series, Doctoral dissertations 144/2012. 
Mauss, M., 1999. Lahja. Helsinki: Tutkijaliitto. (Original: Essai sur de lon. Presses Universitaires de France, 1950.)

Naukkarinen, O., 2011. Tahdikkuus esteettis-eettisenä toimintaperiaatteena. Tiede \& Edistys 4, 315-330.

Nussbaum, M., 2001. The Fragility of Goodness: Luck and Ethics in Greek Tragedy and Philosophy. Cambridge: Cambridge University Press.

Palomäki, S. L., and Toikko, T., 2007. Tekemisen ja kohtaamisen ristiriita vanhustyössä. In: Seppänen, M., Karisto, A., and Kröger, T. eds. Vanhuus ja sosiaalityö. Sosiaalityö avuttomuuden ja toimijuuden välissä. Jyväskylä: PS-Kustannus, 271-288.

Pahl, R., 2000. On Friendship. Cambridge: Polity Press.

Pilcher, J., 1995. Age and Generation in Modern Britain. Oxford: Oxford University Press.

Pinker, S., 2011. The Better Angels of Our Nature: Why Violence Has Declined. New York: Viking.

Pirhonen, J., 2015. Tunnustaminen ja sen vastavuoroisuus vanhustyössä. Gerontologia 29(1), 25-34.

Polanyi, K., 2001. The Great Transformation: The Political and Economic Origins of Our Time. Boston, MA: Beacon Press.

Raittila, H., 2001. Canal Grande. Helsinki: WSOY.

Said, E., 2011. Orientalismi. Helsinki: Gaudeamus. (Original: Orientalism, London: Penguin, 1977.)

Sennett, R., 1999. The Corrosion of Character. The Personal Consequences of Work in the New Capitalism. New York: W.W. Norton.

Sennett, R., 2003. Respect in a World of Inequality. New York: W.W. Norton.

Simmel, G., 2005. Suurkaupunki ja moderni elämä. Kirjoituksia vuosilta 1895-1917. Helsinki: Gaudeamus. (Original: Die Grossstädte und Geistesleben. Jahrbuch der Gehestiftung IX, 1903.)

Sipilä, J., 2011. Hyvinvointivaltio sosiaalisena investointina: älä anna köyhälle kalaa vaan koulutus! Yhteiskuntapolitiikka 4, 359-372.

Sortheix, F., 2014. Values and Wellbeing: An Analysis of Country and Group Influences. University of Helsinki, Publications of the Department of Social Research 2014: 5.

Taylor, C., 1992. Multiculturalism and "the Politics of Recognition". Princeton, NJ: Princeton University Press.

Thompson, S., 2013. Reciprocity and Dependency in Old Age. Indian and UK Perspectives. New York: Springer.

Titmuss, R., 1970. The Gift Relationship: From Human Blood to Social Policy. London: George Allen \& Unwin.

Turner, B., 1989. Ageing, Status Politics and Sociological Theory. British Journal of Sociology 40, 588-606.

Wolff, J., and De-Shalit, A., 2007. Disadvantage. Oxford: Oxford University Press. 